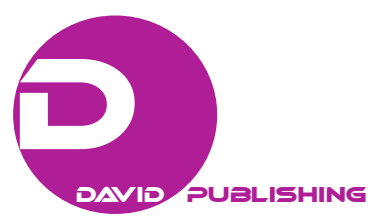

\title{
Social Causes of Arab Youth Radicalizing
}

\author{
Diab M. Al-Badayneh \\ Police College, MOI, Qatar \\ IKCRS, Amman, Jordan \\ Rami A. Al-Assasfeh, Nisreen A. Al-Bhri \\ Mutah University, Alkarak, Jordan
}

\begin{abstract}
The purpose of this study was to examine the impact of macro social factors (states, religion, region, Arab spring, terrorism, unrest (Shoe index), democracy, corruption (GPI), Human development (HDI), low self-control, life stress events (LSE), youth unemployment, religiosity, feeling (fear and anger), youth unemployment and total unemployment) on Arab youth's radicalization. A sample of 6,730 Arab youth age 15-24 years was selected from Kuwait, UAE, KSA, Oman, Qatar, Bahrain, Jordan, Tunisia, Libya, Morocco, Lebanon, Egypt, Gaza and Palestine and Syrian refuges in Jordan. A questionnaire of 43 items to measure radicalization was developed based on the literature review. A construct validity of the scale was estimated by calculating the correlation between radicalization scale and Low self-control scale and found a positive significant relationship $(0.680, \alpha=0.000)$, a sign of validity of the scale. A Reliability of the scale is strong and was estimated by Cronbach's alpha and was 0.947. An average of $46.6 \%$ of the participants was categorized as radicals with standard deviation of 12 . Macro social factors explained $64 \%$ of the variance on radicalization. It has a significant impact on radicalization $(F=$ 807.6, $\alpha=0.000$ ). Each single variable has a significant impact. The analysis revealed three groups of macro determinants of youth radicalization were identified: (1) Geographic factors: state, region, and Arab spring; (2) Social factors: religion, religiously, feelings, LSE and LSC; (3) Human security: unrest, terrorism, democracy, corruption, human development, youth unemployment and employment rate. To alleviate the consequences of radicalization, prevention policies should take in account youth concerns as partners and victims of radicalization. Policies need to focus on radicalization pull and push factors on micro-meso-macro level.
\end{abstract}

Keywords: radicalization, Arab youth, policy implications

\section{Introduction}

There are 22 Arab states (10 states in Africa and 12 in Asia). Arab world has a population of around 422 million people; over half of them are under 25 years of age (UNESCO, 2014). A high fertility in the Arab region, six children per women during the 1980s, has produced a youth bulge aged 15 to 24 years. The number of youth is more than doubled since 1980 and its share in the population at all-time highs. The Arab region has been experiencing a massive youth bulge (Sugita, 2011). By most estimates, youth (15-24 years) in the Arab region constitute approximately $25 \%$ of the population (Assaad \& Roudi-Fahimi, 2007). Youth between the ages (15

Diab M. Al-Badayneh, Professor of Applied Sociology, Police College, MOI; IKCRS.

Rami A. Al-Assasfeh, Ph.D., Department of Sociology, Mutah University.

Nisreen A. Al-Bhri, Ph.D., Department of Sociology, Mutah University. 
and 29) years old represent over 100 million of the current population (Lancaster, 2009). Thirteen million kids between the ages (6 and 15) are currently out of school or never have attended (Desrues, 2012). Arab region is the youngest region in the world (Assaad \& Roudi-Fahimi, 2007). The absolute number of youth is estimated to increase by 12 million by 2025 .

The Bright side of youth bulge can be seen by focusing not on young people as problems but on young people as assets (El-Tawila, 2002; Checkoway et al., 2003) and social capital. Young men and women in the Arab region today are the healthiest, and educated; thus they hold the potential to make a considerable contribution to the human development and human security of the region. "Taking the youth seriously" is not an option but an urgent priority for many countries in the region, which has witnessed the readiness and ability of the young men and women to mobilize the society and become an integral part of the social transformations in tandem with the Arab spring in 2011 (Sugita, 2011, p. 4). Youth can be "powerful catalysts" in their own and their community's development. They contribute to community change by acting as resources and citizens in their communities (Afifi, 2011). Furthermore, youth cohorts can be a vehicle for economic and human development, rather than conflict, as fertility and dependency ratios are declining, opening the potential for demographic dividends. The opportunity literature, (greed perspective) focuses on the structural conditions that provide opportunities for a rebel group to wage war against a government (Collier, 2000). According to the opportunity perspective, rebellion is feasible only when the potential gain from joining a rebel or terrorist organization is so high and the expected costs so low that certain individuals will favor joining over alternative income-earning opportunities (Urdal, 2012, p. 1).

The dark side of youth bulge can be seen when the association made between the youth bulge, high youth unemployment on one hand and with violence, radicalization and "terrorism" on the other hand (Al-badayneh, 2009, 2011, Al-badayneh, Al Hassan, \& Almawajdeh, 2016, Al-badayneh, Khelifa, \& Al Hassan, 2016; Afifi, 2011; Hendrixson, 2004). Youths consider a security threat with their maladjustment to strains produced by poverty and unemployment and lack of democracy and freedom. The International Labor Organization believes up to 75 million young people alone are jobless in the Arab world (ASDA, 2016, p. 5). Even in poverty alleviation, a health and educated youth can be a pillar fighting poverty since youth will have smaller family size comparing with their families. The motive-oriented tradition, or grievance perspective, has its origins in relative deprivation theory and tends to see the eruption of political violence as a rational means to redress economic or political grievances (Gurr, 1970, p. 223). Motives for committing political violence can be economic, like poverty, economic recession or inequality, or political, like lack of democracy, absence of minority representation or self-governance. Most of the literature on youth bulges and political violence falls into this tradition. It focuses on how large youth cohorts crowding the labor market or the educational system, confronting lack of political openness, and agglomerated in urban centers may feel aggrieved, paving the way for political violence (Choucri, 1974; Goldstone, 2001; Urdal, 2012, p. 2).

\section{Youth's Concerns}

Regional survey reports $^{1}$ (i.e., The 8th Annual ASDA'A Burson-Marsteller, 2015, 2016) have supported

\footnotetext{
1 The 8th Annual ASDA'A Burson-Marsteller Arab Youth Survey 2015, and 2016 was conducted by international polling firm PSB to explore attitudes among Arab youth in 16 countries in the Middle East and North Africa GCC: Bahrain, Kuwait, Oman, Qatar, Saudi Arabia and UAE. Levant \& Yemen: Jordan, Iraq, Lebanon, Palestine and Yemen. North Africa: Algeria, Egypt, Libya, Morocco and Tunisia, with 3,500 face-to-face interviews, and 50:50 males:females. http://www.arabyouthsurvey.com/en/home.
} 
the argument that Arab youth has experienced personal and collective social strains; leaving them uncertain about the major future issues like democracy and freedom. Such factors like lack of opportunities (relative deprivation), unemployment and lack of freedom are pushing them to join terrorist groups like ISIS. As can be seen from Figure 1, the major Arab youth's concerns in 2015 and 2016. Top concern has been the rose of terrorist groups in specific ISIS. And the third top concern consistent for the two years has been the unemployment. Uncertainty about future is the core concern. This is reflected in most issues (rise of ISIS, terrorism, unemployment etc.).
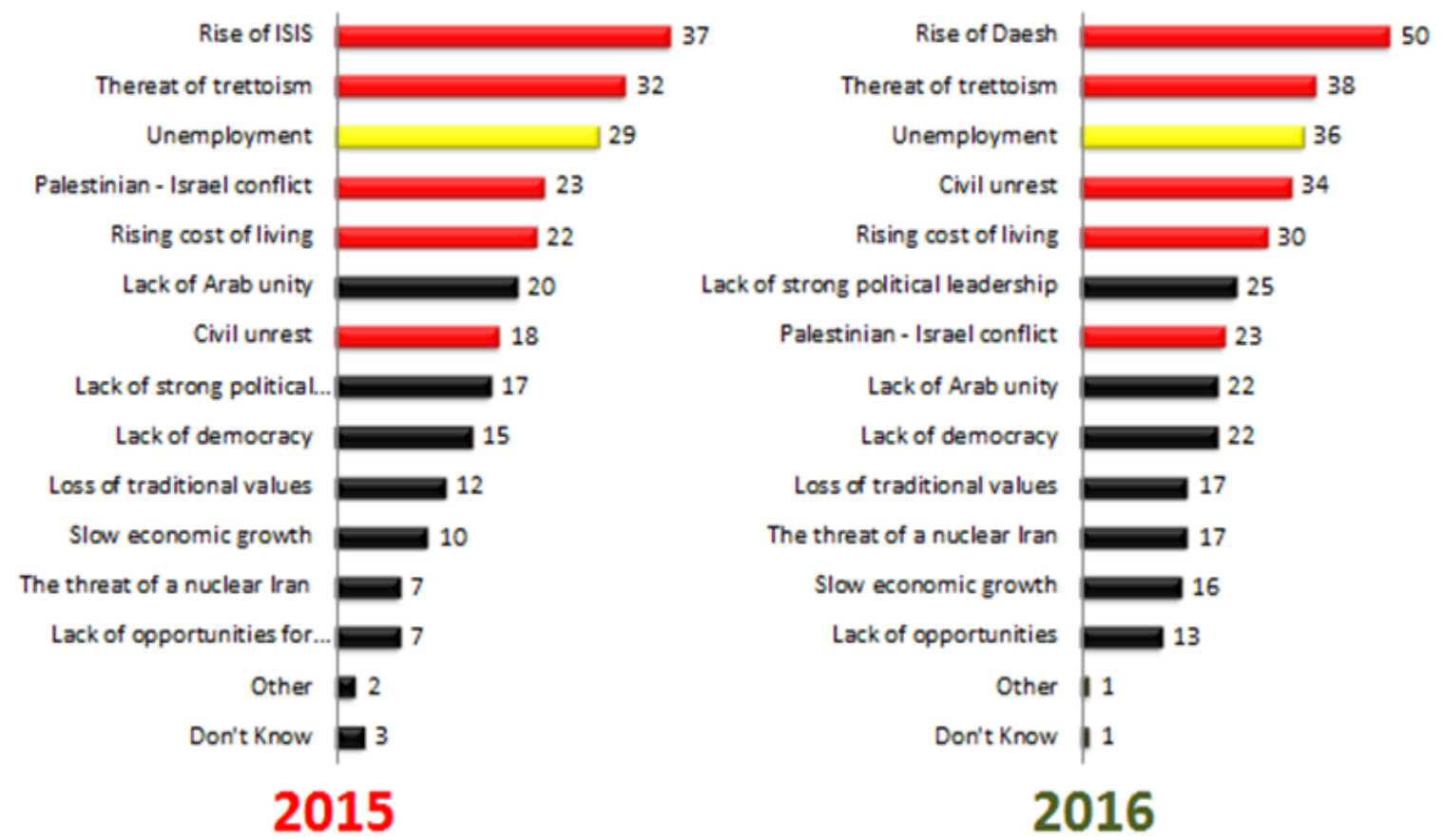

Figure 1. Youth views of the most obstacles the MENA region is facing (Source of Data: ASDA, 2016, p. 1, 25).

Youth are fearing future terrorism, study showed youth were concerned $42 \%$ that they personally, or a friend or relative being the victim of future terrorist attack in Jordan. Also, students were worried that there will be another terrorist attack on Jordan soil, region and global in the near future with average of 5.4 (54\%), 5.3 (535), and $6(60 \%)$ respectively. Factor analysis produced three factors explaining $63.9 \%$ of the variance, the first factor explained (personal threat) $41.9 \%$ of the variance, the second factor (national threat) explained $14 \%$ of the total variance and the third factor (external threats "regional and global") explained $7.8 \%$ of the variance (Al-Badayneh, Al-khattar, \& Al Hassan, 2011).

\section{Youth Unemployment}

The security implications of the youth population pressure and resource scarcity have received increasing attention over the past decade. Related literature showed that youth play a prominent role in political and social violence as well as in social uprising and movements. Since the start of the Arab spring, Arab youth has put under the umbrella of the national security and intelligence. Youth has been the target for radial and terrorist groups' recruitment (Goldstone, 1991, 2001; Urdal, 2012, p. 1; Al-badayneh, 2016). Zakaria (2001, p. 24) argues that youth bulges, combined with slow economic and social change, have provided a foundation for an Islamic 
resurgence in the Arab world.

As can be seen from Figure 2 three Arab states (Qatar, UAE, \& Bahrain) reported youth unemployment rate within the world average. An unemployment rate in Lebanon, Algeria, Kuwait, and Morocco were within the Arab Average. The unemployment rate in the rest of the Arab states were greater average than the Arab unemployment average. The Arab region stands out in terms of its overall unemployment problem; it is the only region where unemployment exceeded 10 percent in 2011 for the population aged 15 years or older. Youth unemployment has been at very high levels for decades in this region. Youth unemployment increased by 5 percent in 2011. The already very high youth unemployment in the Arab region rose sharply in the wake of the Arab Spring and was hovering at around 27 percent in 2012, the highest in the world and twice the global rate for youth. Furthermore, it is almost three times higher than the 10 percent unemployment rate for the working age population in the region (Mirkin, 2013, p. 22).

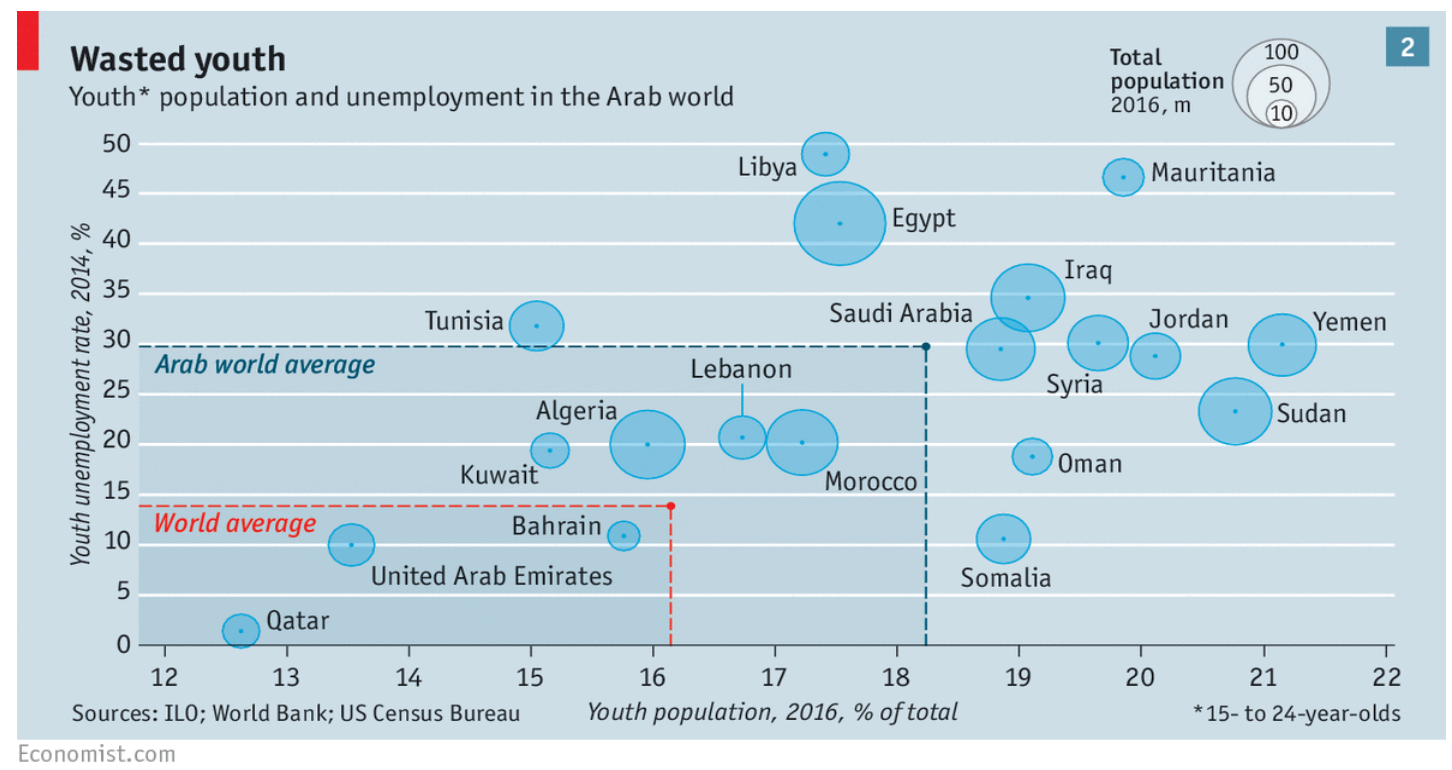

Figure 2. Arab youth unemployment, 2016.

\begin{abstract}
Arab Unrest
The Arab region has experienced considerable uprising, social movements and ongoing instability and conflict in many countries (i.e., Syria, Iraq, Lebanon, Somalia, Egypt, Jordan, Tunisia, Bahrain, Libya, Sudan, and Yemen). Numerous factors have been cited as causes for unrest sweeping across the region, including the absence of democracy, repression, authoritarianism, corruption, cronyism, alienation, disenfranchised religious and ethnic groups and minorities, lack of socio-economic development, poverty and the meddling of foreign powers (Mirkin, 2013, p. 8). A question raised by the Economist years ago right after the Arab spring "Will the Arab Spring initiate a blossoming of democracy or spread extremism, conflict and violence? Part of the answer to this question is that yes it has moved to conflict and chaos and that attributed to the deep state and to the external intervention. Political regimes with other social systems resist, fear of change and fear the loose of power. Youth have been seeking to be free from need and free from fear, demanding justice, equity, human rights, and reform. These demands have translated by sates powers as threatening to the status quo. Figure 3 represents the value of Arab sates on Shoe-Thrower's index for unrest. The index predicted Arab spring in Yemen, Egypt, Syria, Iraq,
\end{abstract}


Tunisia, and Libya. Other countries like Jordan and Morocco are also has experienced social movements.

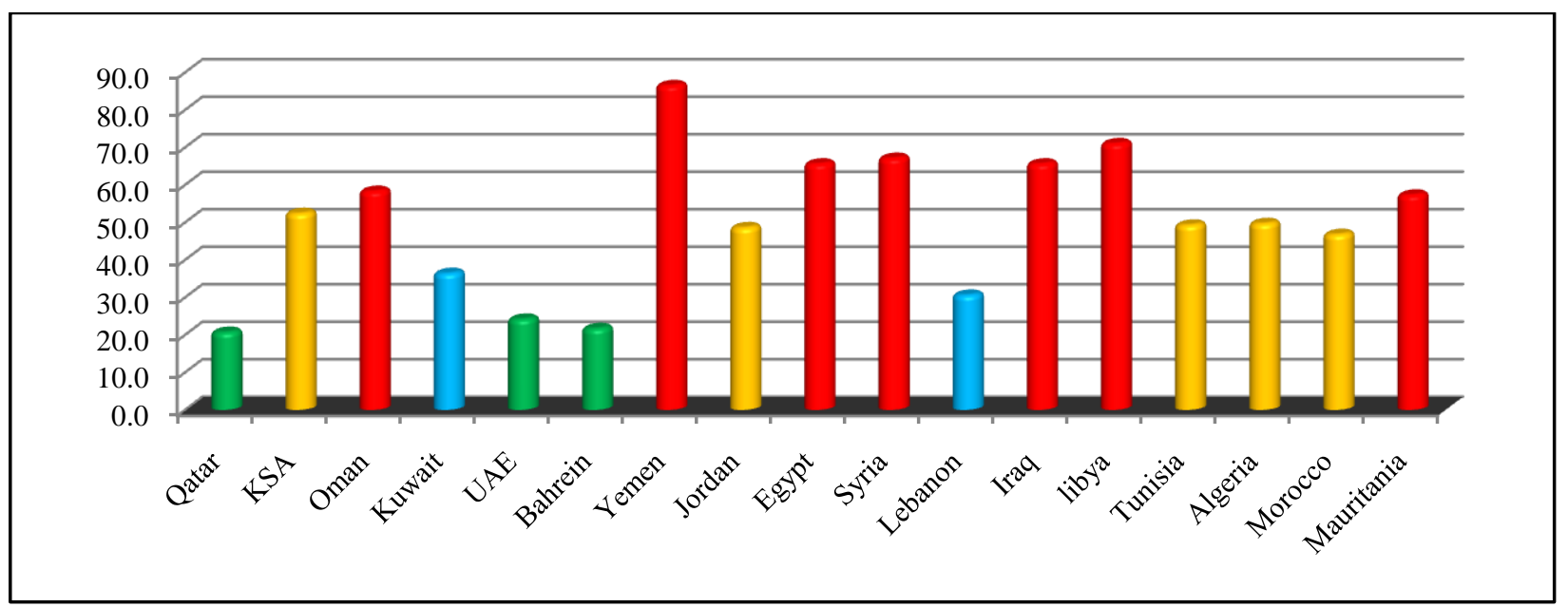

Figure 3. The Shoe-Thrower's index for unrest in the Arab world. Data: Arab unrest index The Shoe-Thrower's index, http://www.economist.com/blogs/dailychart/2011/03/arab_unrest_0.

\section{Youth Radicalization}

Radicalization of young people is above all viewed as a security risk. Push factors and pull factors are operating on youth being involved in radicalization. Unemployment for example, pushes youths toward radicalization. De-radicalization policies pull youth toward the mainstream society. Numerous macro factors have been cited for radicalization, including the absence of democracy, repression, authoritarianism, corruption, cronyism, alienation, lack of socio-economic development, poverty and unemployment (World Bank, 2008). Almost all research has been carried out from different disciplines (i.e., a legal, criminological or socio-psychological perspective) have focused on detecting and containing the risks posed by radicalization (Marion, Stijn, \& Micha, 2013, p. 276). Radicalization is a process that can be prevented and combated by different means (i.e., legal, criminal justice, social, education and others).

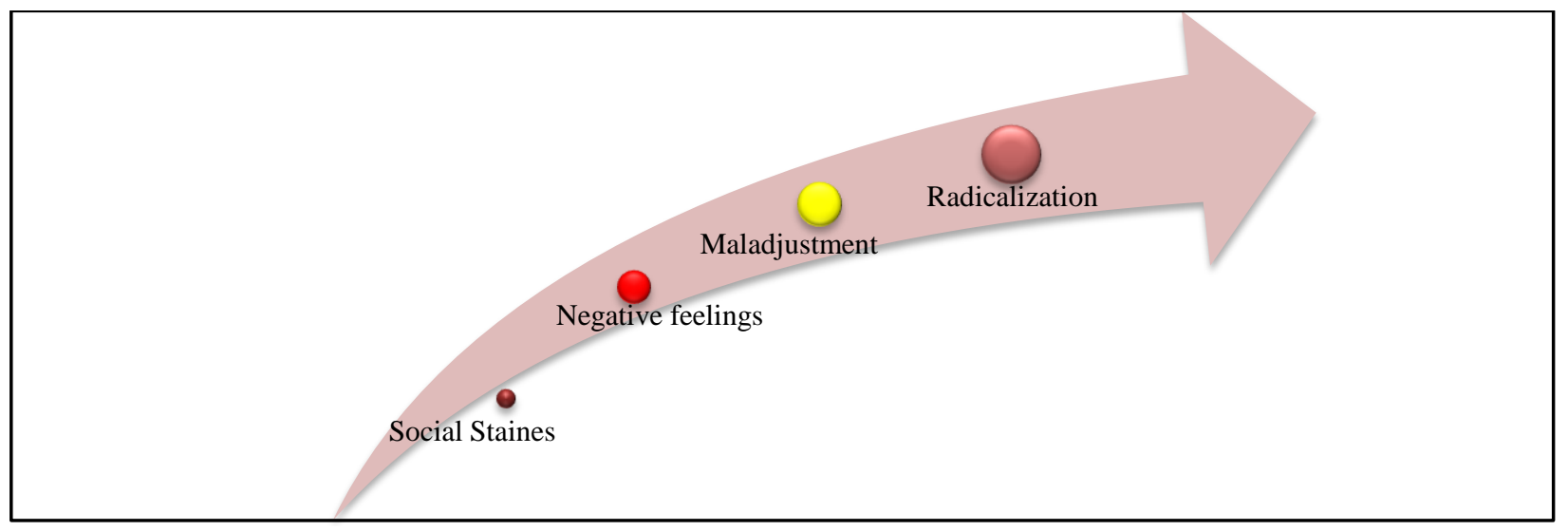

Figure 4. Youth's path to radicalization.

As can be seen from Figure 4, youth's path to radicalization starts as a response to the micro and macro levels of stains, where youth lack opportunities, then youth are pushed to a maladjustment means to cope with such strains. As a consequence youth develop negative feelings toward others. Finally, the choice then is to join a 
radical group and become radical. From zero to Hero an expression used by Marion et al. (2013, p. 276) to understand reasons for young people to become radicalized and to describe the process of involving in radical group. The core assumption is that youth in general are vulnerable to radicalization. A more vulnerable segment of them is a marginalized, unemployed and alienated. Youth has needs to be fulfilled and squeeze by society. A radical group provides a membership that serves as reference point for adult behavior and actions. It provides sense of identity, security and protection. It gives a perspective and importance in life. Radical groups make youth internalizes a zero-order radical beliefs and ideology. Such beliefs and ideology enlarge the importance of bound, membership and loyalty to the group in the eyes of its members and the significant others (Al-badayneh \& Al hasan, 2016). The rush that comes with a new recruit's rise from "invisible" to "recognized" gives more satisfaction than he or she has ever felt before. It leaves a powerful impression and provides these young people with a new direction in life (Marion et al., 2013, p. 276).

\section{Empirical Literature Review}

In a recent review of the growing body of literature on this subject, it was found that empirical studies suggest that youth bulges are associated with an increased risk of political violence. Radicalization is variously blamed upon exposure to ideology, victimization, alienation, socialization, social networks, the internet, deficiencies in family bonds, trauma, relative social and economic deprivation, and "cultures of violence" (Bjorgo \& Horgan, 2008; Dalgaard-Nielsen, 2008; McCauley \& Moskalenko, 2008; Silber \& Bhatt, 2008; Wiktorowiz, 2005, cited in Brown \& Saeed, 2015, p. 1953).

Despite concerns raised over the extant understanding of radicalization, the UK's current strategy considers radicalization as a cause for state concern. It aims to counter radicalization at different levels and stages including interrupting the "process of radicalization" for individuals who show signs of being radicalized (HMG, 2011a, $p$. 8). The UK counterterrorism strategy, CONTEST, specifically in the Preventing Violent Extremism (PREVENT) section, views the signs and causes of radicalization as disenfranchisement, a search for identity at times of crisis, increasing religiosity and religious symbolism, implicitly some form of psychological weakness, and a connection with others holding such beliefs, including through virtual networks. It is also seen to be identifiable at particular locations, including mosques, hospitals, schools, and universities (HMG, 2011b, pp. 68, 85, 108; HMG, 2013, cited in Brown \& Saeed, 2015, p. 1954).

The relationship between human development, peace, corruption and terrorism incidents in the Arab World from 1970 through 2007 showed a negative relationship between the total number of terrorists; incidents and fatalities and human development value; human poverty; average gender inequality. Findings also present a significant negative relationship between peace index and the total number of terrorists, and incidents. All measures of corruption: freedom from; control of corruption \& corruption perception index were significantly correlated with the total number of terrorists; incidents and fatalities. A positive relationship was found between unemployment and the number of terrorists; incidents and fatalities. A positive significant relationship between terrorists' incidents and Arab youth unemployment, and Arab Youth share of unemployment. Moreover, findings show that total number of terrorists; incidents and fatalities do vary according to the human development index (HDI) level (high, medium and low development). ANOVA analysis has shown significant differences in terrorist's incidents, fatalities and injuries, according to human development levels significant differences have been found in freedom from corruption; control corruption, and corruption perception according to human development levels (Al-badayneh, 2009). 
Al-badayneh (2011) argued that university (Jordan) is under risk. The university as incubator for radicalization showed the average percentage of the prevalence of the radical beliefs was $64.4 \%$ among the university students. Radical beliefs like martyrdom, unity by force, hatred \& jihad were highly prevailed among university students. Findings raised the attention to the university security and encountering radical beliefs dissemination among university students. Security policies are needed to prevent hijacking the university by radicalism, and transiting the university as incubator for radicalization and path to terrorism.

Another study showed a significant impact of political affiliation, political participation and life satisfaction on religious, political and violent radicalization among university students. Significant impact was found in the impact of the political participation and life satisfaction on religious radicalization. Political affiliation was found significant on political radicalization. Moreover, Political affiliation was found significant on violent radicalization. Finally life satisfaction was found significant on political radicalization (Al-Badayneh, Al Hassan, \& Almawajdeh, 2016).

Radicalizing Arab university students is becomes a global emerging threat. Factor analysis produced five factors explaining $45 \%$ of the total variance of radicalization. The first factor labeled "political radicalization" explained $18.5 \%$ of the variance, the second factor "religious radicalization" explained $12.7 \%$, the third factor "violent radicalization" explained $6.4 \%$ of the variance, the fourth "group radicalization" accounted for $4 \%$, and the fifth factor "social radicalization" only accounted for $3 \%$ of the total variance. Significant differences in student radicalization were found according to the geographical region of the university (North, Center and South). However, no significant differences were found in radicalization as it relates to gender, and type of college (i.e., Humanities vs. Pure Sciences) (Al-Badayneh, Khelifa, \& Al Hassan, 2016).

The relationship between religious behavior and radicalization among Arab youth reveals some implications for terrorism recruitment and de-radicalization. A significant relationship between religious behavior and college student's radicalization (social, religious, political, violent, and personal radicalization) was found. A strong significant relationship exists between all types of radicalization and each religious commitment: prayer (with exception to personal radicalization), and religious impact on individual's life (with exception to political radicalization). Religious attitudes have significant impact on developing radical behavior and actions. Social injustice and strains foster the identification and development of radical attitudes. The threat of radicalization is not limited to the uses of violence or the threat of its use, but it may also be the driving force of other forms of detrimental impact on society. Religious behavior has an impact on general radicalization $(F=$ 13.446, $\alpha=0.000$ ).

Almost all predictors of religious behavior have a significant impact on each type of radicalization. Commitment to religion has a significant effect on all types of radicalization with exception to social and group radicalization. Prayer has the least effect, a significant effect on all types of radicalization with exception to general, social, religious and group radicalization. Radicalization of students' beliefs and thoughts can be seen as a semi zeroorder belief, students' beliefs and radical ideas transmitted to them by their parents, teachers, colleagues and social network. Radicalization developed in incubators like family, school, and universities within smaller groups where bonding, peer pressure, and indoctrination gradually changes the individual's view to a radical view (Al-Badayneh \& Al Hassan, 2016).

\section{Method}

Sample. A sample of 6,730 youth from Kuwait (404), UAE (500), KSA (517), Oman (511), Qatar (297), 
Bahrain (201), Jordan (497), Morocco (499), Tunisia (500), Libya (75), Lebanon (500), Egypt (507), Gaza (500), Palestine (508) and Syrian refugees in Jordan (714), of whom $47 \%$ males and 51\% females. Family size was 5.8 persons, with average of 2 working family members, and $6 \%$ of father were not working compare to $41 \%$ of mothers. In education, $5 \%$ of fathers were illiterate compare to $9 \%$ of mothers. Around half (46\%) of the sample participated in a fight and $44 \%$ used force, and $40 \%$ cheated in exam. On the perception of justice, $18 \%$ did not feel justice and $14 \%$ did not feel equity and $25 \%$ were not satisfied in life.

\section{Research Tool}

A questionnaire has been developed based on the previous research especially spar Radicalization scale (KSA). The questionnaire is consisted of demographic information, family information, social variables, feeling of justice, equality and national pride. Also it contains religiosity variables, use of force, criminality, violence and life stress events and low self-control. And finally radicalization scale (44 items).

Validity and reliability. Construct validity is estimated a construct validity of the scale was estimated by the calculating the correlation between radicalization scale and low self-control scale and found a positive significant relationship $(0.705, \alpha=0.000)$, another estimates was by the relationship between life satisfaction and radicalization. It was expected a negative relation and it was a significant negative relationship $(-117, \alpha=0.00)$, a sign of validity of the scale. A Reliability of the scale is strong and was estimated by Cronbach's alpha and was 0.947 .

\section{Findings}

\section{General Level of Violent Radicalization}

Findings of the present study showed an alarming average percentage of the prevalence of the radical beliefs was found (46.6\%) among the sample. Regression analysis reveals many determinants of youth's radicalization. All determinants of radicalization explained $64.3 \%$ of the variance on radicalization and were significant $(F=$ $807.6, \alpha=0.000)$.

Table 1

Top Ten Radical Statements

\begin{tabular}{lllc}
\hline$\#$ & Item \# & Item & $\%$ \\
\hline 1 & 36 & I consider the rape of a girl of my religion, as the rape of a sister. & 78.00 \\
2 & 34 & I consider the offend to a man of religion, is offend to my father. & 73.00 \\
3 & 10 & I believe that the martyrs in the name of God revives the religion. & 64.00 \\
4 & 44 & Muslim is treated unjust in this world. & 63.50 \\
5 & 31 & Religious law should be the sole source of authority. & 63.00 \\
6 & 35 & I consider the trial of a young man of my religion, is a trial for my brother. & 62.00 \\
7 & 30 & What police are doing is most important than demonstrations to demand freedom. & 59.00 \\
8 & 33 & Committed to the consensus of my relatives in all issues. & 59.00 \\
9 & 38 & To obey all types of authority what students should learn. & 59.00 \\
10 & 16 & My doctrinal religious should be the doctrine of state. & 56.00 \\
\hline
\end{tabular}

The highest radical beliefs and thoughts among youth were about the group commitment and identity such as "the rape of a girl from my religion as the rape of my sister"; "the offend to a man of my religion is offend to my father"; and the centrism of the religion "religious law should be the sole source of authority" and grievance the "Muslim is treated unjust in this world". Also, one fascism statement ranked high "Students should learn to 
obey all types of authority". Another group commitment statement was ranked high "the trial of a young man of my religion is a trial for my brother".

\section{Determinants of Youth's Radicalization}

Regressing macro factors (state, religion, region, Arab spring, unrest, terrorism, democracy, corruption, human development, low self-control, life stress events, feelings, religiously, youth unemployment and total unemployment) on radicalization reveals a multiple relationship $(R=0.802)$ and these variables explained $64.3 \%$ of the variance on youth's radicalization.

Table 2

ANOVA Table Regressing Independent Variables on Radicalization Total Score

\begin{tabular}{lrrcrl}
\hline Source & Sum of Squares & \multicolumn{1}{c}{ df } & Mean Squares & F & Sig \\
\hline Regression & $8,099,006.066$ & 15 & $539,933.738$ & 807.600 & 0.000 \\
Residual & $4,488,752.249$ & 6,714 & 668.566 & & \\
Total & $12,587,758.314$ & 6,729 & & & \\
\hline
\end{tabular}

There major determinants of youth radicalization were categorized: (1) Geographic factors: state, region, and Arab spring; (2) Personal Factors: religion, religiously, feelings, youth unemployment, LSE and LSC; (3) Human security: unrest, terrorism, democracy, corruption, human development, and employment rate. All determinant were statistically significant.

Table 3

Regression Coefficients ${ }^{a}$

\begin{tabular}{|c|c|c|c|c|c|}
\hline \multirow{2}{*}{ Model } & \multicolumn{2}{|c|}{ Unstandardized Coefficients } & \multirow{2}{*}{$\begin{array}{l}\text { Standardized } \\
\text { Coefficients } \\
\text { Beta }\end{array}$} & \multirow[t]{2}{*}{$t$} & \multirow{2}{*}{ Sig. } \\
\hline & $\mathrm{B}$ & Std. Error & & & \\
\hline (Constant) & -23.449 & 6.004 & & -3.906 & 0.000 \\
\hline State & 3.265 & 0.223 & 0.338 & 14.670 & 0.000 \\
\hline Religion & -2.238 & 0.753 & -0.025 & -2.971 & 0.003 \\
\hline region & 5.626 & 2.569 & 0.062 & 2.190 & 0.029 \\
\hline Spring & 0.823 & 0.129 & 0.078 & 6.361 & 0.000 \\
\hline Unrest Shoe Value & 0.993 & 0.073 & 0.339 & 13.577 & 0.000 \\
\hline Terrorism Index 2015 & -9.964 & 0.501 & -0.266 & -19.905 & 0.000 \\
\hline Democracy Index & -7.952 & 0.443 & -0.255 & -17.936 & 0.000 \\
\hline Corruption Index & 1.421 & 0.044 & 0.471 & 32.144 & 0.000 \\
\hline HDI value & 0.268 & 0.055 & 0.047 & 4.856 & 0.000 \\
\hline LSC & 2.609 & 0.047 & 0.474 & 55.882 & 0.000 \\
\hline LSE & -0.544 & 0.225 & -0.019 & -2.417 & 0.016 \\
\hline Feelings & -1.100 & 0.199 & -0.045 & -5.535 & 0.000 \\
\hline Religiosity & 0.488 & 0.161 & 0.024 & 3.035 & 0.002 \\
\hline Youth unemployment & -0.796 & 0.415 & -0.067 & -1.919 & 0.055 \\
\hline Total Unemployment & 0.247 & 0.082 & 0.052 & 3.021 & 0.003 \\
\hline
\end{tabular}

Note. ${ }^{\text {a }}$ Dependent variable: Radicalization.

\section{Discussion}

There are multiple ways to examine the root causes of radicalization and extremism. There is no single cause or pathway into radicalization. There is a wide array of factors and variables on the macro- , meso- , and 
micro-levels that attributed to youth radicalization. Radicalization and terrorism research have indicated that neither poverty nor socio-economic deprivation are direct root causes of terrorism (Ranstorp, 2016, p. 1). This study focused on micro-macro level of analysis examining the impact of geographical factors, social factors and human security factors on youth radicalization.

Finding showed a significant and serious alarm of prevailing radicalism among youth. Social factors on the macro level has strong impact on youth radicalization. Social factors generate social structures that produce general stains that squeeze youth to a negative feelings and maladjustment strategies like violence, radicalization, and terrorism.

Findings revealed three groups of macro determinants of youth radicalization were identified: (1) Geographic factors: state, region, and Arab spring; (2) Social factors: religion, religiously, feelings, LSE and LSC; (3) Human security: unrest, terrorism, democracy, corruption, human development, youth unemployment and employment rate. Significant impact on radicalization is attributed to state. A state represents a political system which include youth's welfare and the extent they enjoy or suffer in their basic rights of freedom, democracy, political participation and all other citizens' concerns. With economic pressure, unemployment, lack of freedom and political participation youth become under social strains that push them toward maladjustment and negative feelings in which all produce radicalization as alternative to their chronic social situation. Arab world can be categorized in four major geographic areas with regard to region: Gulf (GCC (Kuwait, UAE, Qatar, Oman, KSA, and Bahrain) plus Iraq and Yemen), Levant (Jordan, Syria, and Lebanon), Neil river area (Egypt and Sudan) North Africa or Arabian west (Libya, Algeria, Tunisia, and Morocco). Difference was found within and between these regions on all socio-economic and political aspects. In Gulf area (GCC) social and economic similarities are more than difference. A common heterogeneous characterizes shape each geographic area and gulf area are more conservative, Levant and North Africa areas are more liberal areas. Yemen, Iraq, Libya, and Syria and to some extent Egypt are under unrest. Arab world has experienced unrest and social movement in a variant degree. In some negative consequences attributed to the deep state and some other social and political factors, Arab spring push young people to radicalization.

Social factors including religion, religiously, feelings, LSE and LSC. Adopting and practicing a radical version of religion (Mathhab) is the power behind the radical ideology. Looking at the religion beliefs as the scape boat from the suffering, injustice and inequality in the real world. Using the violent radicalization to gain the rewards of luxury life (beautiful women and rivers of wins and honey), in the day after. A growing number of youth has experienced grievances and vengeance and felt a sense of unjust and a "wall of distrust". This means they no longer take an interest in their environment, and its rules. They internalized stigma and lower expectation from the significant other in society. Youth feel unjust treatments and insecurity, and can lead to the development of radical beliefs and acts. Youth in the Arab world have experiencing injustice, lack of dignity, inequity. Youth exposure to many life stress events, like death, family problems, sickness and unemployment. As a coping strategy to such stains and negative feelings youth develop low self-control personality, where they focus on immediate satisfaction and gaining their goals.

A review of the literature by Al-badayneh (2016), Al-Badayneh, Al-khattar, and Al Hassan (2011), Al-Badayneh (2009), Al-Badayneh (2011), Al-Badayneh (2012), Al-Badayneh, Al Hassan, and Almawajdeh (2016), Al-Badayneh and Al Hassan (2016), Al-Badayneh, Khelifa, and Al Hassan (2016), and Schweizer (2007) regarding the impact of social structure and stains on both radicalization and terrorism suggesting that these factors facilitate the activities of radicals and terrorist groups (Al-badayneh, 2009). Hsieh and Pugh (1993) 
provide a meta-analysis study for the relationship between poverty, income inequality and violent crimes. In (34) studies yielded (76) correlation coefficients, all but two (74 study or 97\%) are positive correlation between poverty, income inequality and violent crimes (Hsieh \& Pugh, 1993). Considering the supply side of terrorism, Berrebi (2003) argues that high standards of living and education are positively associated with participation in terrorist activities (Krueger \& Maleckova, 2003).

Human security can be summarized in the free of need and free of fear. There are many factors that threaten the stability of human security including the unrest, terrorism, lack of democracy, corruption, lack of human development, youth unemployment and employment in society. Policies on strengthen social ties and sense of unity, free from need and free from fear requires a social invest in human security rather than military security. Unrest Index in the Arab world developed by the Economist can be seen as accumulative impact of many macro, meso and micro factors. The Arab unrest Index is the result of ascribing a weighting of $35 \%$ for the share of the population that is under 25: $15 \%$ for the number of years the government has been in power; $15 \%$ for both corruption and lack of democracy as measured by existing indices; $10 \%$ for GDP per person; $5 \%$ for an index of censorship and 5\% for the absolute number of people younger than 25. The Arab region faces a challenge of unemployment problem in general; it is the only region where unemployment exceeded 10 percent in 2011 for the population aged 15 years or older. Youth unemployment has been at very high levels for decades in this region (Mirkin, 2013, p. 22) and increased by 5 percent in 2011. The already very high youth unemployment in the Arab region rose sharply in the wake of the Arab Spring and was hovering at around 27 percent in 2012, the highest in the world and twice the global rate for youth. Furthermore, it is almost three times higher than the 10 percent unemployment rate for the working age population in the region (Mirkin, 2013, p. 22).

Empirical evidence support the notion that general strains such as failure of human development and absence of peace in society produce radicalization and terrorism. Some studies on international terrorism found that economic development and social welfare policies are important determinants of terrorism (Li \& Schaub, 2004; Li, 2005). Berrebi (2007) points to a positive association between education and terrorism, while poverty is negatively associated with terrorism.

It is clear that push factors have more impact and strength on youth radicalization than pull factors (preventive factors). The push-factors involve but not limited to: social, political and economic grievances; a sense of injustice and discrimination; personal crisis and tragedies; frustration; alienation; a fascination with violence; searching for answers to the meaning of life; an identity crisis; social exclusion; alienation; marginalization; disappointment with democratic processes; polarization, etc. Where the pull-factors include but not limited to also, are a personal quest, a sense of belonging to a cause, ideology or social network; power and control; a sense of loyalty and commitment; a sense of excitement and adventure; a romanticized view of ideology and cause; the possibility of heroism, personal redemption, etc. (Ranstorp, 2016).

According to Gurr (1970), political violence as the result of collective discontent caused by a sense of relative deprivation. He writes, "'Relative deprivation' is responsible for the tension that develops from a discrepancy between the 'ought' and the 'is' of collective value satisfaction, and that disposes men to violence". This gap between an individual's expected and achieved welfare result in collective discontent. "The primary source of the human capacity for violence appears to be the frustration aggression mechanism... the anger induced by frustration... is a motivating force that disposes men to aggression, irrespective of its instrumentalities". Specifically, Gurr holds that "the greater the intensity and scope of relative deprivation, the greater the magnitude of collective violence. Group relative deprivation is closely linked to collective action, or an act by a group 
member on behalf of the group, aimed at improving group conditions on the whole. People who believe their membership group is relatively deprived are more likely to participate in social movements and actively attempt to change the social system using group strategies (Kawakami \& Dion, 1993; Walker \& Pettigrew, 1984). This might include normative action, violence or terrorism. Disorder and inequality in a state result with increasing attacks on their legitimacy. The people's sense of political community disappears and individuals feel alienation. The social contract that binds individuals and social structures loses its legitimacy. Chaos, or in Durkheim's words, anomie takes the place of social order. Instead of common values which bind society, marginal ideologies (radicalism) often motivate terrorism and lead to the emergence of terrorist ideologies (Kayaoglu, 2007).

\section{Policy Implications}

Any successful policy should engage youth as partners and receivers (targets). Strains and "grievances" are a major cause of radicalization, violent radicalization and terrorism and should be alleviated from youth's life. National policies on preventing youth radicalization need a cultural, social and values immunization against radicalization by enhancing human security pillars including effective citizenship, good education, fighting poverty and unemployment, respect human rights, strengthen democracy and freedom in all aspects of life. Future generation is in danger unless policies and strategies implemented to prevent and fight radicalization. Human security and human development immunize youth against the involvement in the process of radicalization and can divert their radical path to compliant path with social mainstream norms. Youth needs to be protected and be free from need and the fear. Policies of preventing radicalization among Arab youth require multi-level approach (Macro-meso-micro level). It is a multi-faceted social and security problem and needs a multi-partnership approach to prevent it. Findings showed multiple and mutual factors producing radicalization in Universities. Impacts can range from individual, family school to society at large. Radicalization is a cumulative developmental process. It cannot occurs in one trigger incident. Radical families produce radical kids, with radical schools and radical curriculum will produce radical youth, and finely university will continue the process unless the university applies preventive measures against radicalization. Radical Arab students is considered a global security threat (Al-badayneh, Khaliefa, \& Alhasan, 2016).

\section{Preventive Implications}

As terrorism expert Brian Michael Jenkins states, "Terrorists do not fall from the sky ... they emerge from a set of strongly held beliefs. They are radicalized. Then they become terrorists. The best way to prevent youth radicalization is to tackle its causes by understanding why youth become radical, and violent? Strengthing social ties, youth social capital in society and cultural and socially immunizing youth against the radical thoughts and beliefs.

An effective youth preventive policy may operate on three pillars: The target is the youth, the push factors and the pull factors. Youth are vulnerable to all forms of radicalization. They are a vulnerable and marginalized segment in society who feels excluded, disenfranchised, disgruntled, and alienated from the larger society. Religious radicals find the university environment as an ideal environment for recruitment for their political parties and even for terrorist activities. Thus universities become an incubator for radicals (Al-Badayneh, 2010). Youth are the target for recruitment with their reinforcing environment for radicalizing. Push factors that stimulate youth to radical and join radical groups, like youth's identity crises and other social crises like economic pressure, lack of democracy, lack of freedom, unemployment, inequality and unjust and marginalization and 
exclusion from most important life aspects. Exclusion including but not limited to political participation and in decision making and policy formation that reflect their interests. Pull factors that prevent and immune youth from being radical and not to join radical groups, like job, income, education, social investment, family, feeling just and equity, human development, health, democracy, and political participation. Socializing incubators like family, school and university need to install positive curriculum contents that enhance tolerance and respect difference and human rights. This dissuade youth from being involved in radical behavior in future. De-radicalization becomes important to relapse radical prevention to forgo radical actions

Policies emerge from youth perspective is better understand what can be done to help youth and prevent them from being victims of radicalization Youth lack policies in education and development, to rectify this omission, youth needs a revised policies and strategies to be adopted to the global human values. Dissemination of the radicalization can hamper the future of human security and development as well as the social order. (Al-badayneh, Al Hassan, \& Almawajdeh, 2016).

\section{References}

Afifi, R. (2011). Youth as agents of change. Retrieved from http://www.unesco.org/new/fileadmin/MULTIMEDIA/FIELD/Beirut/pdf/YCE\%20_EN.pdf

Al-Badayneh, D. (2009). Human development, peace, corruption, and terrorism in the Arab World. Retrieved from http://ikcrsjo.org/docs/Human_Development_Terrorism-1-2010.pdf

Al-Badayneh, D. (2011). University under risk: The university as incubator for radicalization. Retrieved from http://www.booksonline.iospress.nl/Content/View.aspx?piid=23009

Al-Badayneh, D. (2012). Radicalization incubators and Terrorism recruitment in the Arab world. Retrieved from http://www.nauss.edu.sa/Ar/DigitalLibrary/Books/Pages/Books.aspx?BookId=833

Al-badayneh, D. (2016). Causes of radicalizing among Arab University's students: Policy and preventive implications. Proceedings from Radicalization, Terrorism and Universities. Turkish Police Academy in Ankara.

Al-Badayneh, D., \& Al Hassan, K. (2016). Religious behavior and radicalization among Arab Youth: Implications for Terrorism Recruitment and De-radicalization. In S. Ekici, H. Akdogan, E. Ragab, A. Ekici, \& R. Warnes (Eds.), Countering Terrorist Recrutment in the Context of Armed Counter-Terrorism Operations. IOS press. The NATO Science for Peace and Security Programe.

Al-Badayneh, D., Al Hassan, K., \& Almawajdeh, M. (2016). The impact of political affiliation, political participation and life satisfaction on radicalization among university students. Retrieved from http://www.bjournal.co.uk/BJASS.aspx

Al-Badayneh, D., Al-khattar, A., \& Al Hassan, K. (2011). Fearing future terrorism: Perceived personal, national, regional and international threats of Terrorism. Retrieved from http://ebooks.iospress.nl/publication/25655

Al-Badayneh, D., Khelifa, M., \& Al Hassan, K. (2016). Radicalizing Arab University students: A global emerging threat. Journalism and Mass Communication, 6(2), 67-78.

ASDA'A Burson-Marsteller. (2015). The 7th Annual ASDA'A Burson-Marsteller Arab Youth Survey. Retrieved from 2015.http://www.arabyouthsurvey.com/en/home

ASDA'A Burson-Marsteller. (2016). The 8th Annual ASDA'A Burson-Marsteller Arab Youth Survey 2016. Retrieved from http://www.arabyouthsurvey.com/en/home

Assaad, R., \& Roudi-Fahimi, F. (2007). Youth in the Middle East and North Africa: Demographic opportunity or challenge? Washington, D.C.: Population Reference Bureau.

Berrebi, C. (2003). Evidence about the link between education, poverty and terrorism among Palestinians. Working Papers 856, Princeton University, Department of Economics, Industrial Relations Section.

Berrebi, C. (2007). Evidence about the link between education, poverty, and terrorism among Palestinians. Peace Economics, Peace Science, and Public Policy, 13(1), 1-36.

Bjorgo, T. (2009). Root causes of terrorism: Myths, reality and ways forward. Retrieved from https://uscrow.org/download/warfare/terrorism_and_counterterrorism/Root\%20causes\%20of\%20Terrorism.pdf

Bjorgo, T., \& Horgan, J. (2008). Leaving terrorism behind: Individual and collective disengagement. New York: Routledge.

Brown, K. E., \& Saeed, T. (2015). Radicalization and counter radicalization at British universities: Muslim encounters and alternatives. Ethnic and Racial Studies, 38(11), 1952-1968. 
Checkoway, B., Richards-Schuster, K. R., Abdullah, S., Aragon, M., Facio, E., ... Figueroa, L. (2003). Young people as competent citizens. Press and Community Development Journal, 38(4), 298-309.

Choucri, N. (1974). Population dynamics and international violence: Propositions, insights and evidence. Lexington, MA: Lexington.

Collier, P. (2000). Doing well out of war: An economic perspective. In M. Berdal, \& D. M. Malone (Eds.), Greed and grievance: Economic agendas in Civil Wars (pp. 91-111). Boulder, CO and London: Lynne Rienner.

Dalgaard-Nielsen, A. (2008). Studying violent radicalization in Europe II: The potential contribution of socio-psychological and psychological approaches. DIIS Working Paper, No 2008/3. Copenhagen: DISS.

El-Tawila, S. (2002). Youth in the population agenda: Concepts and methodologies. MEAwards Regional Papers, West Asia and North Africa, No. 44. Cairo: Population Council.

Goldstone, J. A. (1991). Revolution and rebellion in the early modern world. Berkeley, CA: University of California Press.

Goldstone, J. A. (2001). Demography, environment and security. In P. F. Diehl, \& N. P. Gleditsch (Eds.), Environmental Conflict (pp. 84-108). Boulder, CO: Westview.

Gurr, T. R. (1970). Why men rebel. Princeton, NJ: Princeton University Press.

Harrison, A. (2011). Campus Extremism "a Serious Problem” Say MPs and Peers. Retrieved from http://www.bbc.co.uk/news/education-13223026

Hsieh, C. C., \& Pugh, M. D. (1993). Poverty, income inequality, and violent crime: A meta-analysis of recent aggregate data studies. Criminal Justice Review, 18, 182-202.

Kawakami, K., \& Dion, K. (1993). The impact of salient self-identities on relative deprivation and action intentions. European Journal of Social Psychology, 23, 525-540.

Kayaoglu, M. (2007). Does inequality trigger terrorism? In S. Ozeren, I. D. Gunes, \& D. M. Al-Badayneh (Eds.), Understanding Terrorism: Analysis of Sociological and Psychological Aspect (2007) (pp. 99-108). IOS Press \& NATO Public Diplomacy Division.

Krueger, A. B., \& Maleckova, J. (2003). Education, poverty and terrorism: Is there a causal connection? The Journal of Economic Perspectives, 17(4), 119-144.

Lancaster, P. (2009). Youth: the great 21st-century challenge. Middle East, 402, 12-16.

LI, Q. (2005). Does democracy promote or reduce transnational terrorist incidents?. Journal of Conflict Resolution, 49(2), 278-297.

LI, Q., \& Schaub, D. (2004). Economic globalization and transnational terrorism: A pooled time-series analysis. Journal of Conflict Resolution, 48(2), 230-258.

Marion, S., Stijn, S., \& Micha, W. (2013). Ideals adrift: An educational approach to radicalization. Ethics and Education, 8(3), 276-289.

McCauley, C., \& Moskalenko, S. (2008). Mechanisms of political radicalization: Pathways toward terrorism. Terrorism and Political Violence, 20(3), 415-433.

Mill, A. (2009). Failure of George Mason U.'s Persian Gulf Campus sparks concerns about overseas ventures. The Chronicle of Higher Education, 55(27), 1-7.

Mirkin, B. (2013). Arab Spring: Demographics in a region in transition. Retrieved from http://www.arabhdr.org/publications/other/ahdrps/AHDR\%20ENG\%20Arab\%20Spring\%20Mirkinv3.pdf

Ranstorp, M. (2016). The root causes of violent extremism. Retrieved from http://ec.europa.eu/dgs/home-affairs/what-we-do/networks/radicalisation_awareness_network/ran-papers/docs/issue_paper_r oot-causes_jan2016_en.pdf

Silber, M., \& Bhatt, A. (2008). Radicalization in the West: The home-grown threat. Retrieved from http://www.nyc.gov/html/nypd/downloads/pdf/public_information/NYPD_Report-Radicalization_in_the_West.pdf

Sugita, S. (2011). Introduction in UNESCO Regional Bureau for education in the Arab States. Retrieved from http://www.unesco.org/new/fileadmin/MULTIMEDIA/FIELD/Beirut/pdf/YCE\%20_EN.pdf

Urdal, H. (2012). A clash of generations? Youth Bulges and political violence. Retrieved from http://www.un.org/esa/population/publications/expertpapers/Urdal_Expert\%20Paper.pdf

Walker, I., \& Pettigrew, T. F. (1984). Relative deprivation theory: An overview and conceptual critique. British Journal of Social Psychology, 23, 303-310.

World Bank. (2008). Youth and unemployment in Africa: The potential, the problem, the promise. Washington, D.C.

Zakaria, F. (2001). The Roots of Rage. Newsweek, 38(16), 14-33. 